\title{
Neutrophil lymphocyte ratio and therapy response correlation in submandibular abscess with and without diabetes
}

\author{
Dian Ratna Chamora, Mohammad Dwijo Murdiyo, Iriana Maharani \\ Department of Otorhinolaryngology-Head and Neck Surgery \\ Faculty of Medicine, Brawijaya University/Dr. Saiful Anwar General Hospital, \\ Malang
}

\begin{abstract}
Background: Submandibular abscess is one of the most common deep neck abscesses and associated with fatal complications which require adequate management. Diabetes mellitus (DM) is a chronic and complex disease that necessitates ongoing medical care with a multifactorial risk reduction strategy in addition to blood sugar control. The neutrophil lymphocyte ratio (NLR) is a simple marker for the systemic inflammatory conditions. An increased NLR values were found in patients with submandibular abscesses and patients with DM. Purpose: To determine the correlation between NLR to the therapeutic response of patients with submandibular abscesses with and without DM. Method: A cross-sectional study design with secondary data collection from medical records of submandibular abscess patients with and without DM. NLR value was compared between two groups. Correlation between NLR value and therapeutic response was compared between DM and non DM group. Result: The mean NLR of patients with and without DM were respectively $7.65 \pm 4.92$ and $16.53 \pm 11$. There was no significant difference between NLR and good therapeutic response or not in submandibular abscess patients with and without DM ( $\mathrm{p}$ $>0.05$ ). Conclusion: NLR of submandibular abscess patients with DM was lower than without DM. A lower NLR in submandibular abscess patients with DM did not have better response to therapy. Lower LNR in submandibular abscess patients without DM had a better therapeutic response, but it was not statistically significant.
\end{abstract}

Keywords: neutrophil lymphocyte ratio, response to therapy, submandibular abscess, diabetes mellitus

\section{ABSTRAK}

Latar belakang: Abses submandibula merupakan salah satu abses leher dalam yang paling sering ditemui dan berkaitan dengan komplikasi yang fatal sehingga diperlukan penatalaksanaan yang memadai pada pasien. Diabetes mellitus (DM) merupakan penyakit kronis dan kompleks, yang memerlukan perawatan medis berkelanjutan dengan strategi mengurangi risiko multifaktorial selain kontrol gula darah. Rasio neutrofil limfosit (RNL) merupakan penanda sederhana adanya kondisi inflamasi sistemik. Peningkatan nilai RNL ditemukan pada pasien dengan abses submandibula dan pasien DM. Tujuan: Mengetahui hubungan RNL terhadap respon terapi penderita abses submandibula dengan DM dan tanpa DM. Metode: Penelitian cross-sectional, sampel penelitian dari arsip rekam medis rawat inap pasien dengan diagnosis abses submandibula baik dengan komorbid DM dan tanpa komorbid DM. Nilai NLR dibandingkan diantara kedua kelompok. Hubungan nilai RNL dan respon terapi dibandingkan diantara kelompok DM dan tanpa DM. Hasil: Rerata nilai RNL pada pasien abses submandibula dengan komorbid DM sebesar 7,65 + 4,92 dan pada pasien tanpa komorbid DM sebesar $16,53+11$. Tidak ada perbedaan yang signifikan antara nilai $\mathrm{RNL}$ terhadap respon terapi baik dan tidak baik pada pasien abses submandibula dengan komorbid DM dan tanpa DM $(p>0,05)$. Kesimpulan: RNL penderita abses submandibula dengan DM lebih rendah daripada penderita tanpa DM. RNL yang lebih rendah tidak memiliki respon terapi yang lebih baik pada penderita abses submandibula dengan DM. RNL yang lebih rendah memiliki respon terapi yang lebih baik pada penderita abses submandibula tanpa DM, namun tidak bermakna secara statisitik. 
Kata kunci: rasio neutrofil limfosit, respon terapi, abses submandibula, diabetes mellitus

Correspondence address: Dian Ratna Chamora, Department of Oto Rhino Laryngology-Head and Neck Surgery, Faculty of Medicine, Brawijaya University/Dr. Saiful Anwar General Hospital, Malang. Email: dianchamora@gmail.com.

\section{INTRODUCTION}

Submandibular abscess is an abscess that is formed in the (potential) submandibular space located between the deep neck space and commonly caused by spreading infection from tooth (odontogenic), tonsils, salivary gland, and lymph node. The spread of infection could occur by continuation, lymphatic or hematogenous. ${ }^{1,2}$

Several studies find submandibular abscess is a common form of deep neck abscess with prevalence $37.5 \%$ - 57.5\% among all form. ${ }^{1,3,4}$ Meanwhile, at Department of Otorhinolaryngology Dr. Saiful Anwar General Hospital, Malang in 2019, the prevalence of submandibular abscess patient was $56.5 \%$ and odontogenic was the only cause. ${ }^{5}$ Deep neck abscess is associated with fatal complication such as upper airway obstruction, cervical necrotizing fasciitis, mediastinitis, sepsis, et cetera which could cause mortality rate almost $50 \%$ despite adequate antibiotics and aggressive surgical therapy. ${ }^{1,6}$

Diabetes mellitus (DM) is defined as a group of metabolic disorders characterized by the main symptoms of hyperglycemia caused by abnormalities in insulin secretion and/or insulin resistance. DM is a chronic and complex disease that requires long term medical care with multifactorial risk reduction strategy addition to blood glucose control. ${ }^{7,8}$

Hyperglycemia causes alteration in immune system, complement, and antioxidant system which accompanied by vascular insufficiency will increase the risk of infection in diabetic patient. Some studies showed higher mortality rate caused by infection in diabetic patients. ${ }^{9}$ Submandibular abscess with comorbid DM is associated with length of stay and higher complication. ${ }^{10}$ In the Department of Otorhinolaryngology, Dr. Saiful Anwar General Hospital, Malang during the year 2019, deep neck abscess patients with comorbid DM had longer length of stay. ${ }^{5}$

Neutrophil to lymphocyte ratio (NLR) is a marker for systemic inflammation condition. ${ }^{11}$ Furthermore, NLR also could be used as a predictor for surgical therapy in submandibular abscess and as a recovery marker in odontogenic infection. Several studies found the relationship between NLR and the presence of pus, length of stay, and the required antimicrobial dose..$^{11,12}$

NLR value is stable and resistant to physiological and environmental changes, such as dehydration, physical activity and blood samples handling, that can affect the results of the examination. ${ }^{13}$ A study conduct by Dogruel, et al. ${ }^{14}$ found the NLR cut off value of 100 submandibular abscess patients was 5.19. Higher value than the cut off was associated with higher antibiotic dose and prolonged hospital stay. Other study by Şentürk et al. ${ }^{15}$ found the NLR cut off value from 88 peritonsillar abscess patients was 3,08 . This study also found a statistically significant decrease in post treatment NLR value compared to the pretreatment. The NLR value in pretreatment, post treatment and control group were respectively $7.12 \pm$ $4.29,2.60 \pm 1.44$ and $2.02 \pm 0.80$.

DM is associated with chronic low grade inflammation condition that lead to elevated NLR value. ${ }^{16}$ A study by Akujuru found significantly higher NLR in the DM group 
compared to control. The NLR value in DM and control group were respectively $1.40 \pm$ 0.70 and $0.80 \pm 0.30$.

The aim of this study was to compare the value of NLR in submandibular abscess patient with and without DM and to determine the correlation between NLR value and response to therapy in submandibular abscess patient with and without DM.

\section{METHOD}

\section{Population}

The inpatient medical record of submandibular abscess who underwent treatment in the Department of Otorhinolaryngology Dr. Saiful Anwar General Hospital from January $1^{\text {st }}, 2018$ until December $31^{\text {st }}, 2019$. The exclusion criteria were patients who were transferred to another department during the treatment, patients with prior history of antibiotic and surgical treatment, and patient who died before the treatment started. This study was approved by the Ethic Committee of Dr. Saiful Anwar general hospital.

\section{Study Design}

This study was an analytic observational study with a cross sectional approach. Patients were divided into 2 groups, patients with and without DM. NLR value was compared between two groups. Therapeutic response was assessed based on length of stay in hospital and categorized as good response if length of stay less than or equal to 7 days. Correlation between NLR value and therapeutic response was compared between DM and non DM group. All characteristic data were collected and recorded computerized.

\section{Neutrophil lymphocyte ratio}

Neutrophil lymphocyte ratio was obtained by dividing absolute neutrophil value per absolute lymphocyte value taken from blood count examination.

\section{Statistical analysis}

Data were analyzed using SPSS 22 for windows. A $p$-value $<0.05$ were considered statistically significant.

\section{RESULT}

A total of 15 inpatient medical records were included in this study which were divided into 2 groups, first group with comorbid DM as many as 6 medical records and second group without comorbid DM as many as 9 medical records. The sociodemographic, baseline clinical characteristic, duration of disease, length of stay, and surgery performed were shown in Table 1.

Tabel 1. Sociodemographic and clinical characteristic of participants

\begin{tabular}{lcc}
\hline \multicolumn{1}{c}{$\begin{array}{c}\text { Characteristic } \\
(\mathbf{N = 9 )}\end{array}$} & $\begin{array}{c}\text { With DM } \\
\mathbf{n}(\mathbf{\%})\end{array}$ & $\begin{array}{c}\text { Without DM } \\
\mathbf{n}(\%)\end{array}$ \\
\hline Age (years, mean \pm SD) & $50.33 \pm 9.54$ & $33.56 \pm 17.78$ \\
$\begin{array}{l}\text { Age (years) } \\
\leq 20\end{array}$ & & $2(22.2)$ \\
$21-30$ & & $2(22.2)$ \\
$31-40$ & $1(16.7)$ & $2(22.2)$ \\
$41-50$ & $2(33.4)$ & $1(11.1)$ \\
$>50$ & $3(50.1)$ & $2(22.2)$ \\
Sex & & $6(66,7)$ \\
Male & $3(50)$ & $3(33.3)$ \\
Female & $3(50)$ & $8.22 \pm 2.86$
\end{tabular}




\section{Chief complaint \\ Neck swelling \\ Dyspnea}

Duration of complaint

(days, mean $\pm \mathrm{SD}$ )

Odontogenic Infection

Spreading to other deep neck space

Surgical Treatment

Incision drainage

tracheostomy + incision drainage

$\begin{array}{cc}6(100) & 8(88.9) \\ & 1(11.1) \\ 12 \pm 7.95 & 4.5 \pm 1.93 \\ 6(100) & 9(100) \\ 2(33.3) & 4(44.4) \\ 6(100) & \\ & 4(44.4) \\ & 5(55.6)\end{array}$

SD: Standard Deviation

There was a significant difference in the neutrophil absolute count and blood glucose level between submandibular abscess patient with and without DM. The $p$ value was $<0.05$. (Table 2)

There was a difference microbial etiology obtained from culture swab result between submandibular abscess with and without DM. (Table 3)

Table 2. The comparison of blood profile between submandibular abscess patient with and without DM

\begin{tabular}{|c|c|c|c|}
\hline Blood profile & With DM & Without DM & p - value \\
\hline $\begin{array}{l}\text { Leukocytes } \\
\left(10^{3} / \mu \mathrm{L}, \text { mean } \pm \mathrm{SD}\right)\end{array}$ & $16.35 \pm 6.69$ & $18.49 \pm 2.62$ & 0.488 \\
\hline $\begin{array}{l}\text { Neutrophil } \\
\left(10^{3} / \mu \mathrm{L}, \text { mean } \pm \mathrm{SD}\right)\end{array}$ & $9.97 \pm 4.55$ & $15.47 \pm 2.77$ & $0.012^{*}$ \\
\hline $\begin{array}{l}\text { Lymphocytes } \\
\left(10^{3} / \mu \mathrm{L}, \text { mean } \pm \mathrm{SD}\right)\end{array}$ & $1.6 \pm 0.86$ & $1.39 \pm 0.86$ & 0.659 \\
\hline NLR $($ mean $\pm \mathrm{SD})$ & $7.65 \pm 4.92$ & $16.53 \pm 11$ & 0.058 \\
\hline $\operatorname{Albumin}(\mathrm{g} / \mathrm{dL}$, mean $\pm \mathrm{SD})$ & $3.53 \pm 0.62$ & $3.99 \pm 0.37$ & 0.093 \\
\hline $\begin{array}{l}\text { Blood Glucose Level } \\
(\mathrm{mg} / \mathrm{dL}, \text { mean } \pm \mathrm{SD})\end{array}$ & $334.67 \pm 48.87$ & $106.33 \pm 18.4$ & $<0.001^{*}$ \\
\hline \multicolumn{4}{|c|}{ SD: Santard Deviation, ${ }^{*}$ Significant P Value } \\
\hline Microbe & & With DM & Without DM \\
\hline Pseudomonas aurigenosa $(\mathrm{n}, \%)$ & & & $1(11.1)$ \\
\hline Streptococcus sanguinis (n,\%) & & & $2(22.2)$ \\
\hline Staphylococcus epidermidis (n,\%) & & $2(33.3)$ & $3(33.3)$ \\
\hline Klebsiella Pneumoniae (n,\%) & & $3(50)$ & \\
\hline Staphylococcus aureus $(\mathrm{n}, \%)$ & & $1(16.7)$ & \\
\hline Streptococcus aginosus (n,\%) & & & $1(11.1)$ \\
\hline Streptococcus auregenosus (n,\%) & & & $1(11.1)$ \\
\hline Steril $(\mathrm{n}, \%)$ & & & $1(11.1)$ \\
\hline
\end{tabular}


Antibiotic sensitivity test showed several antibiotics were sensitive to 1 type of microbe, therefore the result would not be presented with percentage.
There was no significant difference in NLR between good response therapy and bad response therapy with $p$ value $>0.05$. (Table 5)

Table 4. Antibiotic sensitivity test result

\begin{tabular}{|c|c|c|}
\hline Antibiotic & With DM & Without DM \\
\hline Ciprofloxacin & 3 & \\
\hline Benzylpenicillin & 1 & 2 \\
\hline Levofloxacin & 1 & 2 \\
\hline Cefotaxim & & 2 \\
\hline Ceftriaxon & 2 & 3 \\
\hline Clindamycin & 1 & 5 \\
\hline Amikacin & & 2 \\
\hline Cefepime & 1 & 1 \\
\hline Ceftazidime & & 1 \\
\hline Piperacillin & & 1 \\
\hline Aztreonam & & 1 \\
\hline Trimetophrim sulfamethoxazole & 3 & 1 \\
\hline Meropenem & & 1 \\
\hline Gentamicin & 4 & 3 \\
\hline Tigecycline & & 2 \\
\hline Oksilin & 3 & 1 \\
\hline Amoxicillin clavulanate & 1 & \\
\hline Cefazoline & 1 & \\
\hline Eritromycin & 1 & 1 \\
\hline Linezolid & & 1 \\
\hline Vankomycin & & 1 \\
\hline Ampicillin & & 2 \\
\hline Linkomycin & & 1 \\
\hline
\end{tabular}

Table 5. The Comparison in NLR between good response and bad response

NLR

P - value

Good Response

Bad Response

\begin{tabular}{|c|c|c|c|}
\hline $\begin{array}{l}\text { With DM } \\
(\text { mean, } \pm \text { SD) }\end{array}$ & $8.11 \pm 7.25$ & $7.38 \pm 2.77$ & $0.88^{\mathrm{a}}$ \\
\hline $\begin{array}{l}\text { Without DM } \\
\text { (Mean, } \pm \text { SD) }\end{array}$ & $8.87 \pm 4.74$ & $22.66 \pm 10.92$ & $0.50^{\mathrm{b}}$ \\
\hline
\end{tabular}

SD: Standard Deviation, ${ }^{a}$ Independent T- test between NLR and response to therapy in submandibular abscess with DM, ${ }^{\mathrm{b}}$ Mann - Whitney test between NLR and response to therapy in submandibular abscess without DM 


\section{DISCUSSION}

The age of submandibular abscess patients with DM in this study were between $35-63$ years, with mean age $50.33 \pm 9.54$ years. While, the age of submandibular abscess patient without DM were between $8-58$ years, with mean age $33.56 \pm 17.78$ years. This finding was similar with a study conducted by Das et al. ${ }^{5}$ which also found mean age patient with DM was higher. In our study, male to female ratio was different between patients with and without comorbid DM. In patients with comorbid DM male to female ratio was $1: 1$, while in patients without comorbid DM the male to female ratio was $2: 1$. No gender difference in patients with comorbid DM also found in Lin et al. ${ }^{18}$ On the contrary, several studies found male subjects were much higher than female in both condition. ${ }^{19,20}$

Length of stay submandibular abscess with comorbid DM was shorter than without comorbid DM in our study. This result contradicted several studies that had found correlation between DM and length of stay. In addition to DM, several factors that influenced length of stay were age, revision surgery, another deep neck space involved, and blood sugar level. ${ }^{10,21}$

Almost all of submandibular abscess patients in our study had neck swelling as a chief complaint, with shorter duration of complaint in submandibular abscess without comorbid DM subjects. Several studies also found neck swelling as a chief complaint in submandibular abscess. ${ }^{19,20}$ There were some reason for longer duration of complaint in comorbid DM, including slower progressivity so most patients needed treatment for focal infection eradication and symptoms relief.

All of our patients had odontogenic focal infection. Other study also found odontogenic as the source of infection. ${ }^{20,22}$

Hyperglycemia in DM cause immune system dysfunction, reduced salivary production, alters saliva composition and reduced salivary $\mathrm{pH}$. Besides, DM also heightened metabolic activity of oral microbiota that alters the natural equilibrium of dental biofilm. This condition lead to susceptibility to caries dentis, periodontal disease, oral mucosa lesion and infection..$^{23,24}$

It could be seen in Figure 1 that the basement membrane in salivary gland diabetic patient is changed by microvascular damage, consequently boosting leakage of glucose from ductal cell that causes escalated salivary dan gingival crevicular glucose level. This surge leads to decreased fibroblastic activity causing intensification of plaque accumulation. The plaque metabolizes the salivary glucose to lactic acid as a result of which $\mathrm{pH}$ of saliva is decreased and an upsurge of acidophilic bacteria takes place. Long term and uncontrolled of glucose leakage into the saliva causing heightened metabolic activity of oral microbiota. This alters the natural equilibrium of dental biofilm and leads to dental decay and periodontal complications. ${ }^{24}$ The diagrammatic depiction is shown in Figure 1.

Leukocyte count of submandibular abscess patient with DM were lower than those without DM in our study. This condition could be related to age where older age is associated with decreased leukocyte count. There are several causes for lower leukocyte count, including changes in the bone marrow and its functioning, changes in the structure and function of hematopoietic stem cells which cause formation of new leukocyte less efficiently, and deterioration of the immune system related to age. ${ }^{25}$ Several literature found the association between NLR and age, blood glucose level, and HbA1c. ${ }^{16,26}$

The most common bacteria in submandibular abscess cases with DM is Klebsiella pneumoniae. Klebsiellapneumoniae is a tissue-invasive and hypervirulent strains, possesses polysaccharide capsule for survival and immune evasion during infection. 
The presence of a thick capsule at the cell surface protects Klebsiella pneumoniae from opsonization, phagocytosis, binding and internalization by macrophages, neutrophils, epithelial cells and dendritic cells. ${ }^{27}$ Patients with DM had alteration in the innate immune system response by monocytes through low TLR4 expression resulting in interference with the recognition of bacterial lipopolysaccharides. In addition, there was also a reduced response of $\mathrm{TNF} \alpha$ accompanied by impaired downstream IL10 signaling and decreased expression of CD163. The impaired monocyte function causes an immunosuppressive condition in DM patients so that it is easy to develop opportunistic infections caused by Klebsiella pneumoniae. ${ }^{28}$

In this study there were no significant association between NLR and therapeutic response, whereas several study found association between NLR and therapeutic response. Besides NLR, factors that influence the therapeutic response are smoking, expanding to other deep neck spaces, age and complication. ${ }^{12,19,29,30}$

The difference in this study result between NLR and therapeutic response was caused by several reasons. First, CT-Scan was not performed routinely. The involvement of other deep neck spaces was determined by the presence of pus from aspiration puncture, so the real number of deep neck space involved could not be determined. Secondly, all of the submandibular abscess patients had been given empirical antibiotic therapy, namely combination of ciprofloxacin and metronidazole. Based on antibiotic sensitivity test in submandibular abscess patients with DM, there were 3 samples sensitive to ciprofloxacin. This might be the reason for good response in diabetic patient even though 1 of the 3 sample had NLR value 16.377. Thirdly, this study used secondary data from medical record, so there were some confounding factors which had not been evaluated such as $\mathrm{HbA} 1 \mathrm{c}$ value and smoking.
In conclusion, NLR of submandibular abscess patients with DM was lower than without DM. A lower NLR in submandibular abscess patients with DM did not have better response to therapy. Lower NLR in submandibular abscess patients without DM had a better therapeutic response, but it was not statistically significant. These results could provide an overview for submandibular abscess patients without DM that higher NLR value would increase the risk of longer length of stay in hospital.

\section{REFERENCE}

1. Khavdu PJ, Fefar AD, Mistry SN, Chavada PS. A study of deep neck spaces infection in present era at tertiary care teaching hospital. Int J Otorhinolaryngol Head Neck Surg. 2018; 4(5): 1276.

2. Pardal-Peláez B, Pardal-Refoyo JL, OchoaSangrador C, González-Serrano J, MonteroMartín J, López-Quiles J. Analysis of the prevalence of dental origin of deep neck infections. J Oral Maxillofac Surg Med Pathol. 2018; 30(2): 180-86.

3. Priyamvada S, Motwani G. A Study on Deep Neck Space Infections. Indian J. Otolaryngol. Head Neck Surg. 2019; 71(1): 912-17.

4. Rijal S, Romdhoni AC. Bacteria Pattern, Results of Antibiotic Sensitivity Test, and Complications of Deep Neck Abscess Patients in Dr. Soetomo General Hospital. Biomolecular and Health Science Journal. 2018; 1(2): 124-30.

5. Medis TP. Laporan Tahunan Poliklinik Khusus Laring Faring THT-KL. Rumah Sakit Umum Daerah dr. Saiful Anwar; 2019.

6. Belaldavar BP, Khadilkar MN, Havaldar R. A demographic analysis of deep neck space infections in a tertiary care centre in Belagavi. Pain. 2016; 27: 61.4.

7. Petersmann A, Nauck M, Müller-Wieland D, Kerner W, Müller UA, Landgraf R, et al. Definition, classification and diagnosis of diabetes mellitus. Experimental and clinical endocrinology \& diabetes. 2018; 126(07): 406-10.

8. Soelistijo SA, Novida H, Rudijanto A, Soewondo P, Suastika K, Manaf A, et al. Konsesnsus Pengelolaan dan Pencegahan 
Diabetes Melitus Tipe 2 Di Indonesia 2015. PB. PERKENI; 2015.

9. Magliano DJ, Harding JL, Cohen K, Huxley RR, Davis WA, Shaw JE. Excess risk of dying from infectious causes in those with type 1 and type 2 diabetes. Diabetes Care. 2015; 38(7): 1274-80.

10. O'Brien KJ, Snapp KR, Dugan AJ, Westgate PM, Gupta N. Risk factors affecting length of stay in patients with deep neck space infection. The Laryngoscope. 2020; 130(9): 2133-37.

11. Russell CD, Parajuli A, Gale HJ, Bulteel NS, Schuetz P, de Jager CP, et al. The utility of peripheral blood leucocyte ratios as biomarkers in infectious diseases: A systematic review and meta-analysis. J Infect. 2019; 78(5): 339-48.

12. Gallagher N, Collyer J, Bowe C. Neutrophil to Lymphocyte Ratio as a Prognostic Marker of Deep Neck Space Infections Secondary to Odontogenic Infection. Br J Oral Maxillofac Surg. 2020.

13. Vatankhah N, Jahangiri Y, Landry GJ, McLafferty RB, Alkayed NJ, Moneta GL, et al. Predictive value of neutrophil-tolymphocyte ratio in diabetic wound healing. J. Vasc. Surg. Cases. 2017; 65(2): 478-83.

14. Dogruel F, Gonen Z-B, Gunay-Canpolat D, Zararsiz G, Alkan A. The Neutrophil-toLymphocyte ratio as a marker of recovery status in patients with severe dental infection. Medicina oral, patologia oral y cirugia bucal. 2017; 22(4): e440.

15. Şentürk M, Azgıı İ, Övet G, Alataş N, Ağirgöl B, Yilmaz E. The role of the mean platelet volume and neutrophil-tolymphocyte ratio in peritonsillar abscesses. Braz. J. Otorhinolaryngol. 2016; 82(6): 662-67.

16. Duman TT, Aktas G, Atak BM, Kocak MZ, Erkus E, Savli H. Neutrophil to lymphocyte ratio as an indicative of diabetic control level in type 2 diabetes mellitus. African health sciences. 2019; 19(1): 1602-06.

17. Akujuru EE, Aprioku JS, Okerengwo AA. Circulatory levels of pro-inflammatory cytokines (IL-6 and IL-1 $\beta$ ) and neutrophillymphocyte ratio (NLR) in diabetic patients in Nigerian population. Comp Clin Path. 2020:1-7.

18. Lin H, Tsai CS, Chen Y, Liang J. Influence of diabetes mellitus on deep neck infection. J Laryngol Otol. 2006; 120(8): 650.

19. Das R, Nath G, Mishra A. Clinicopathological profile of deep neck space infection: a prospective study. Indian J. Otolaryngol. Head Neck Surg. 2017; 69(3): 282-90.

20. Setiawan PDA, Putra IDAE. Karakteristik penderita abses submandibular di departemen tht-kl rsup sanglah denpasar. MEDICINA. 2020; 51(2): 153-58.

21. Zheng L, Yang C, Zhang W, Cai X, Kim E, Jiang B, et al. Is there association between severe multispace infections of the oral maxillofacial region and diabetes mellitus? J. Oral Maxillofac. Surg. 2012; 70(7): 1565-72.

22. Velhonoja J, Lääveri M, Soukka T, Irjala $H$, Kinnunen I. Deep neck space infections: an upward trend and changing characteristics. Eur. Arch. Oto-Rhino-L. 2020; 277(3): 863-72.

23. Atsmoni SC, Brener A, Roth Y. Diabetes in the practice of otolaryngology. Diabetes \& Metabolic Syndrome: Clinical Research \& Reviews. 2019; 13(2): 1141-50.

24. Ahmad P, Akhtar U, Chaudhry A, Rahid U, Saif S, Asif JA. Repercussions of diabetes mellitus on the oral cavity. European J Gen Dent. 2019; 8(3):55.

25. Chmielewski P. Leukocyte count, systemic inflammation, and health status in older adults: a narrative review. AnthropologicAl review. 2018; 81(1): 81-101.

26. Sefil F, Ulutas KT, Dokuyucu R, Sumbul AT, Yengil E, Yagiz AE, et al. Investigation of neutrophil lymphocyte ratio and blood glucose regulation in patients with type 2 diabetes mellitus. Int. J. Med. Res. 2014; 42(2): 581-88.

27. Chung PY. The emerging problems of Klebsiella pneumoniae infections: carbapenem resistance and biofilm formation. FEMS microbiology letters. 2016; 363(20).

28. Khondkaryan L, Margaryan S, Poghosyan D, Manukyan G. Impaired inflammatory response to LPS in type 2 diabetes mellitus. Int J Inflam. 2018; 2018.

29. Reddy MS, Reddy C. Clinicopathological, microbiological and radiological evaluation of deep neck spaces infections. Int $J$ Otorhinolaryngol Head Neck Surg. 2018; 4(2):409-12.

30. Yew CC, Ng MP, Ling XF, Tew MM. Orofacial infection and influencing factors on prolonged hospital stay: A four year retrospective study of 207 cases. J. Oral Maxillofac. Surg. Med. Pathol. 2020. 